Results

Some results are shown in table 3 in which the metal contents in ion exchangers are given relative to the content in ion exchangers that were placed in the 'standard river' - that flowing from Taseq lake, near Narssaq in South Greenland. To convert to absolute $\mathrm{ppb}$ the relative values have to be multiplied with the concentrations in Taseq river which have not yet been determined.

Some interesting correlations between water content and bedrock can be gleaned from the results. The river water in the Ilimaussaq area is seen to be characterised by high fluoride, zinc and lead contents - products of the Ilímaussaq alkaline intrusion. The known chromite occurrences in the Fiskenæsset area can be recognised in the slightly higher $\mathrm{Ni}$ and $\mathrm{Cr}$ contents, but the Ca-rich anorthosites which form a dominant part of the Precambrian basement in that area, are not reflected in the water analyses.

In East Greenland, at Mesters Vig, where Tunnelelv drains the area where the exhausted lead-zinc mine is situated, the ion exchangers were filled with lead and zinc to over the upper detection limit. It is somewhat surprising that cadmium is not present in a higher amount in the water. The two rivers sampled in the Scoresby Sund area show rather high $\mathrm{Cu}, \mathrm{Cr}$ and $\mathrm{Cd}$, and extremely high $\mathrm{Ni}$ values, particularly the 'Geigen Elv', i.e. the river north-east of Mudderbugt in southeastern Milne Land. Unfortunately only one sample from this latter locality was available for analysis.

\title{
Reference
}

Andersen, S., Bailey, J., Karup-Møller, S., Løkkegaard, L., Rose-Hansen, J., Steenfelt, A. \& Sørensen, H. 1972: Research projects on the Ilimaussaq alkaline intrusion, South Greenland. Rapp. Grønlands geol. Unders. 55, 38-40.

\section{AIRBORNE GEOPHYSICAL SURVEY IN CENTRAL EAST GREENLAND}

\section{Bjarne Leth Nielsen and Hans Christian Larsen}

In 1971 aeroradiometric work was carried out in the Scoresby Sund region (see Nielsen, 1972; Løvborg \& Nielsen, 1973). In 1973 an airborne geophysical programme was begun in East Greenland between $72^{\circ}$ and $76^{\circ} \mathrm{N}$. The main topics of this programme were a regional radiometric reconnaissance coupled with an airborne magnetic survey. The greatest importance was attached to the radiometric project, which is a collaboration between GGU and the Danish Atomic Energy Commission's Research Establishment, Ris $\varnothing$.

GGU and Ris $\varnothing$ supplied 7 and 6 personnel respectively and these were joined 
by a pilot and engineer from Vængir Airtransport Co., Iceland. The participants and the aircraft, a chartered Britten Norman Islander, were based at the camp at Stordal in Muskusoksefjord between Mesters Vig and Daneborg. A short period of field work took place with support from the GGU cutter Jytte.

It is planned to continue the airborne survey and to intensify the field work in the coming years.

In July almost the whole area between $72^{\circ}$ and $76^{\circ} \mathrm{N}$ was photographed from the air. This work was performed with a Turbo Hawk Commander aircraft from Ehrenström Flyg AB, Stockholm, and conducted by personnel from the Geodetic Institute, Denmark. Both this aircraft and the Britten Norman Islander were chartered by GGU through Grønlandsfly A/S.

\section{Airborne radiometric survey}

The airborne gamma-spectrometer was designed and constructed at Ris $\emptyset$. It is a four channel spectrometer equipped with six $6 \times 4^{\prime \prime} \mathrm{NaI}$ (Tl) detectors. A radar altimeter and an automatic $35 \mathrm{~mm}$ camera were connected to the spectrometer system. All data were recorded on punched tape and in addition the count rate in the gross-counting channel, the altitude and the magnetic data were registered on a strip chart recorder.

The flight line coverage of the investigated areas was inhomogeneous since routes were defined by contour flying along fjords, valleys, glaciers, etc. The air speed was almost constant at $70 \mathrm{~m} . \mathrm{p} . \mathrm{h}$. and the ground clearance was in average almost 300 feet. All major geological formations were investigated except areas of Tertiary basalts. The purpose was to select and specify favourable areas or specific geological formations for more detailed uranium exploration, reflected in an above average radioactivity and to classify such formations as either possible source or host rocks. Although the main data at this preliminary stage are still unprocessed this aim can be considered successful and furthermore, a number of radioactive anomalies have been detected. Based on a rough division of the area into geological units their possible potentials of radioactive elements is briefly presented below. The general geochemical behaviour of uranium and thorium during orogenic evolution and in succeeding periods of sedimentation is excellently demonstrated in the reconnaissance data.

\section{Pre-Caledonian and Caledonian crystalline complexes}

A systematic distinction between the many different rock types has not been possible during the flights. Nevertheless, it is considered that the wide range of radioactivity recorded within these complexes can lead to a discrimination based on the final spectrometric data. Radioactive anomalies of possible economic importance were found at a few localities in 'quartzitic schist to gneiss' (nomenclature of Koch \& Haller, 1971). 


\section{Precambrian and Lower Palaeozoic sediments}

The Eleonore Bay Group, the Tillite Group and the Cambro-Ordovician sediments generally hold a low radioactivity. The highest levels were found in dark red claystone belonging to the Multicoloured Series of the Eleonore Bay Group.

\section{Late Caledonian and Devonian intrusives and volcanic rocks}

Syn- and post-tectonic intrusive granites and Devonian rhyolites and tuffs are among the most radioactive rocks detected. They are possible source rocks for epigenetic mineralisation in the surrounding Devonian and Carboniferous molassetype sediments. Important radioactive anomalies were recorded in rhyolites in the Hudson Land - Gauss Halvø region. Limited ground investigations were spent on some of these localities.

\section{Devonian and Carboniferous continental sandstone}

Although possessing a medium level of radioactivity no major anomalies were detected in the post-folding molasse-type sediments. The reconnaissance flights however proved that these formations deserve more detailed inspection.

\section{Mesozoic sedimentary formations}

The marine Mesozoic sediments, as expected, were shown to be poorly radioactive and only limited attention ought to be given to these rocks in the future work.

\section{Airborne magnetic survey}

The magnetic survey was performed with a Geometrics airborne magnetometer, type $\mathbf{G}$ 803. The sensor was mounted in the aircraft in a tail stinger. During August diurnal variations in the magnetic field were recorded with a Geometrics G 806 magnetometer at the base camp at Stordal. All magnetic data were recorded in analogue form on strip chart recorders. From 1974 this registration will probably be digitated on punched tape. The magnetic data are divided into two groups:

1. Magnetic data recorded during the spectrometer flight conditions, that is single profiles at a speed of 70 m.p.h. and a ground clearance of approximately 300 feet.

2. Magnetic profiles (without radiometric recording) at a speed of 140 m.p.h. and at a barometric altitude of 4000 to 8000 feet.

1. The low altitude magnetic data are strongly influenced by near surface magnetic sources and are therefore of economic geological interest. 
In the Precambrian, Upper Palaeozoic and Mesozoic sedimentary formations the magnetic response showed a steady course with long wave undulations which probably, besides diurnal variations and latitude dependance, reflect variations in the thickness of the sediments blanketing the crystalline substratum. Superimposed on this curve, magnetic anomalies reflect intrusions, sills, dykes etc. emplaced in the sediments. The superimpositions may in some cases indicate magnetic source rocks for syn- or epigenetic mineralisation in the sediments. Such mineralisations (mainly pyritic) however, do not cause large disturbances in the magnetic field and none of them were detected during the flight.

In the pre-Caledonian and Caledonian terrain the magnetic course was unsettled showing many short wave undulations (anomalies mainly due to either magnetite or pyrrhotite or both). It was often possible to correlate such variations with basic bodies, faults or rust zones in the rocks. Several of these anomalies deserve a closer examination.

2. Five magnetic profiles were flown at altitudes from 4000 to 8000 feet. The profiles are approximately E-W and cover Jameson Land (two profiles), Traill $\varnothing$ - Kempes Fjord (two profiles) and Kap Biot - Werner Bjerge - Stauning Alper (one profile). The base station magnetometer indicated unstable magnetic conditions during the flights, so that interpretation depends on corrections not yet calculated. However a few preliminary conclusions can be drawn. The profiles on Traill $\varnothing$ - Kempes Fjord show variations which can be correlated with fault patterns of the area. Also, a distinction between Caledonian migmaties and gneisses and sediments of the Eleonore Bay Group becomes obvious from the magnetic curves. The Werner Bjerge intrusion displays a strong positive magnetic anomaly which could indicate an extensive ultrabasic body at depth. This view is supported by ultrabasic rocks outcropping in the south-eastern corner of the intrusion.

\section{References}

Koch, L. \& Haller, J. 1971: Geological map of East Greenland $72^{\circ}-76^{\circ}$ N. Lat. (1:250 000). Meddr Grønland 183.

Løvborg, L. \& Nielsen, B. L. 1973: Processing and interpretation of radiometric flight data from central East Greenland. Rapp. Grønlands geol. Unders. 55, 48-51.

Nielsen, B. L. 1972: Aeroradiometric survey in the Scoresby Sund region, East Greenland. Rapp. Grønlands geol. Unders. 45, 42-43. 